\title{
Exploring Language, Literacy, and Identity Connections through Play-Based Education in Rural, Remote, and Indigenous Communities
}

\author{
BURCU YAMAN NTELIOGLOU \\ Brandon University \\ SHELLEY STAGG PETERSON \\ University of Toronto
}

The starting point for this issue of Language and Literacy was a meeting of teachers who work with young children in northern rural and Indigenous communities in four Canadian provinces, together with researchers from Brazil, Canada, the Netherlands, and New Zealand. A Social Sciences and Humanities Research Council Connections Grant (SSHRC) provided the funding to bring everyone together to the Ontario Institute for Studies in Education at the University of Toronto in May, 2016 in order to create a dialogic platform between researchers, educators and collaborators to engage in collaborative analysis and knowledge production focusing on young children's oral language and writing development in rural, remote and Indigenous contexts.

The teachers are participating in a six-year action-research project funded by a SSHRC Partnership Grant, entitled Northern Oral Language and Writing through Play (NOW Play), aiming to support children's oral language and writing development, and their educators' pedagogical and research capacities. The project responds to a need to examine and challenge dominant metrocentric curricula, research and practice perspectives (Corbett, 2015) that "tend to position the rural in deficit rather than as different" (Corbett \& White, 2014, p. 1). The project also responds to research showing that Indigenous children are not being well served by Euro-centric curricula and teaching practices that are carried out by teachers with inadequate understandings of Indigenous cultures, languages, epistemologies and beliefs (Cherubini, Hodson, Manley-Casimir, \& Muir, 2010; Nardozi, Restoule, Broad, Steele, \& James, 2014).

At the time of the meeting, participating teachers and early childhood educators had been video-recording children's play interactions and photographing written work that accompanies play in their kindergarten, grade one and Aboriginal Head Start classrooms for two years. Selected video and photograph data were released to researchers collaborating on the project for their analyses and insights on what the data show about children's language, literacy and conceptual learning. The collaborators, bringing their experience and knowledge from the fields of Indigenous education, speech-language pathology, early writing, and play in early childhood, presented the results of their analysis and proposed implications for classroom practice and teachers' action research at the Toronto meeting. Some of those presentations were revised to become the papers in this special issue.

With the overarching goal of informing practice, these papers do not take the conventional research report format usually found in Language and Literacy. Their emphasis is on implications for classrooms and starting points for classroom-based research. Additionally, because collaborators whose papers are included in this special issue had not been part of the data collection process and had access to a small portion of the NOW Play data gathered over two years, their papers emphasize ways in which the literature and their previous research within their international 
contexts open up new ways to think about the NOW Play data. Their papers do not include the research questions and methods for the data collection. This information can be found in publications by some of the NOW Play researchers (Peterson, 2017; Peterson, Eisazadeh, Rajendram, \& Portier, submitted; Portier \& Peterson this volume; Yaman Ntelioglou, McIntyre and Palmer-Clarke, submitted). As summarized in the following paragraphs, collaborators, with their multidisciplinary theoretical lenses and diverse cultural backgrounds, have provided interesting insights into ways of supporting the language and literacy of young Indigenous and non-Indigenous children.

Focusing on the Calls to Action by Canada's Truth and Reconciliation Commission, and the need to support the literacy achievement of Aboriginal and non-Aboriginal children in Northern, rural and remote Canadian communities, the first two articles examine culturally sensitive playbased approaches in early learning and child care environments. In their article Anderson, Horton, Kendrick, and McTavish provide and extensive historical background of the concept of "funds of knowledge" and provide a model of how "funds of knowledge" were actualized with young children analyzing data from an Aboriginal early learning context from NOW Play Manitoba sites. Building on the discussion on culturally sensitive approaches in language and literacy education, Peltier, an Anishinaabe scholar, in her article presents case narratives, including a narrative that focuses on NOW Play data from the Aboriginal Head Start Program in Manitoba drawing conceptually and theoretically on the Aboriginal pedagogy she developed from her research in an elementary school. She proposes that this Anishinaabe pedagogy can be considered as a framework for a family literacy model.

The articles in this special issue illuminate the cognitive, social and affective potentials of play-based pedagogy for language and literacy learning. Language, literacy and identity connections through play-based education are further examined from an international perspective in the article by Joanna Williamson and Helen Hedges from New Zealand, the article by Gisela Wajskop from São Paulo, the article by Resi Damhuis and Eefje van der Zalm from the Netherlands. Williamson and Hedges stress the importance of local and culturally responsive frameworks to empower children's voices bringing into focus aspects of Aotearoa New Zealand's bicultural and bilingual early childhood curriculum framework, Te Whāriki, and ideas from the corresponding early childhood narrative assessment framework developed by Māori early childhood academics for Māori children, Te Whatu Pōkeka. Wajskop explores the connections between play-based learning and literacy drawing on data from an action research with 285 children in impoverished areas of São Paulo. She argues that "by enriching children's oral skills with the reading of books, teachers create opportunities to turn playing into a literate activity". In their article, Damhuis and van der Zalm explore the role of interaction and dialogue for language development during play-based classroom practices sharing findings from their empirical study with teachers and students in three preschool institutes in the Netherlands. Working within the learning community teachers from preschool and kindergarten they propose what they term as a "provocative approach" in order enrich student interaction during play and create a rich verbal learning environment for first and additional language learners.

With the understanding that early experiences and development in writing are significant for literacy development, another international collaborator of the NOW Play project from New Zealand, Judy Parr, examines how play-based approaches support early writers through the examination of writing samples from kindergarten and grade one children in three Indigenous Northern Communities in Ontario and three kindergarten classrooms in a Northern Alberta that are part of the NOW Play project. The last article by Shelley Stagg Peterson and Christine Portier 
presented in this special issue describes an action research project conducted as part of the larger NOW Play in order to explore the design and use of an observation/formative assessment tool, Observing Children's Use of Language (OCUL), that allows teachers to examine the ways in which children use language to carry out social purposes during typical dramatic and collaborative play in kindergarten and grade one classrooms.

The examination of a range of theoretical perspectives about language, literacy and identity connections through play-based approaches in education presented in this special issue aims to inform advocacy and ongoing culturally-relevant practice to develop young Aboriginal and nonAboriginal children's oral language and literacy development in their first as well as additional languages.

\section{Acknowledgements}

We would like to thank to the Social Sciences and Humanities Research Council for funding this Partnership Grant, entitled Northern Oral Language and Writing through Play (NOW Play) and the Connections Grant that provided the funding to bring researchers, teacher-participants and international collaborators that made collaborative data analysis shared in this special issue possible. We also would like to thank all the peer reviewers for their vital contributions throughout the busy academic year.

\section{References}

Cherubini, L., Hodson, J., Manley-Casimir, M., \& Muir, C. (2010). Closing the gap at the peril of widening the void: Implications of the Ontario Ministry of Education's policy for Aboriginal education. Canadian Journal of Education, 33(2), 329-355.

Corbett, M. (2015). Towards a rural sociological imagination: Ethnography and schooling mobile modernity. Ethnography and Education, 10(3), 263-277.

Corbett, M., \& White, S. (2014). Introduction: Why put the 'rural' in research? In M. Corbett \& S. White (Eds.), Doing educational research in rural settings: Methodological issues, international perspectives and practical solutions, (pp. 1-4). New York: Routledge.

Nardozi, A., Restoule, J., Broad, K., Steele, N., \& James, U. (2014). Deepening knowledge to inspire action: Including Aboriginal perspectives in teaching practice. In Education,19 (3), $108-122$.

Peterson, S.S. (2017). Developing a play-based communication assessment through collaborative action research with teachers in northern Canadian Indigenous communities. Literacy, 51(1), 36-43.

Peterson, S.S., Eisazadeh, N., Rajendram, S., \& Portier, C. (submitted for review). Social purposes of young children's language in dramatic and block play in northern rural and Indigenous Canadian classrooms. Journal of Research in Childhood Education.

Portier, C., \& Peterson, S.S. (2017). Rural northern Canadian teachers' discoveries about young children's oral language. Language and Literacy.

Yaman Ntelioglou, B., McIntyre L., \& Palmer-Clarke Y. (submitted for review). Teaching and Learning in a Multi-Grade Classroom: Supporting Rural Children's Language/Literacy Development. Teaching and Teacher Education. 